\title{
Announcements
}

INTERNATIONAL CONFERENCE ON HIGH PERFORMANCE COMPUTING (HPIC'95)

Goa (India); December 27-30, 1995. Enquiries to:

V.K. Prasanna, Gen. Co-Chair

EEB 244, Dept. of EE-Systems

University of Southern California

LOS ANGELES CA 90089-2562

USA (E-mail: prasanna@halcyon.usc.edu.)

\section{NINTH INTERNATIONAL CONFERENCE ON}

\section{VLSI DESIGN}

Bangalore (India); January 3-6, 1996. Enquiries to:

N. Ranganthan

Dept. of CSE

University of $\mathrm{S}$. Florida

4202 E Fowler Avenue, ENG 118

TAMPA Florida 33620

USA

(E-mail: ranganat@knuth.csee.usf.edu)

FOURTH INTERNATIONAL WORKSHOP ON ARTIFICIAL INTELLIGENCE IN ECONOMICS AND MANAGEMENT - AIEM4

Tel Aviv (Israel); January 8-10, 1996. Enquiries to:

Phillip Ein-dor

Faculty of Management

Tel Aviv University

TEL AVIV

69978 ISRAEL

(Tel. +972 36408 071;

E-mail: eindor@aiem96.tau.ac.il.)

1996 INTERNATIONAL ZÜRICH SEMINAR ON DIGITAL COMMUNICATIONS - BROADBAND COMMUNICATIONS: NETWORKS, SERVICES, APPLICATIONS, FUTURE DIRECTIONS

Zürich (Switzerland); February 19-23, 1996. Enquiries to:

Dr Plattner

TIK

ETHZ

8092 ZÜRICH

SWITZERLAND

(Fax +411632 10 35;

E-mail: izs96-pc-chair@tik.ethz.ch.)

\section{INTERNATIONAL CONFERENCE ON} DISTRIBUTED PLATFORMS - ICDP'96 Dresden (Germany); February 27-March 1, 1996. Enquiries to:

Alexander Schill

Dept. of CS

Dresden University of Technology
D-01062 DRESDEN

GERMANY

(Tel. +49 3514575 261;

E-mail: icp96@ibc.inf.tu.dresden.de.)

FIFTH INTERNATIONAL CONFERENCE ON MANAGEMENT OF TECHNOLOGY

Miami, Florida (USA); February 27-March 1, 1996.

Enquiries to:

MOT 1996

University of Miami

School of Continuing Studies

P.O. Box 248005

CORAL GABLES FI. 33124-1610

USA

(Tel. +305 284 4777; fax +305284 3318)

EIGHTEENTH INTERNATIONAL CONFERENCE

ON SOFTWARE ENGINEERING - ICSE-18

Berlin (Germany); March 25-29, 1996. Enquiries to:

H. Dieter Rombach

AG Software Engineering Fachbereich Informatik

Univ. Kaiserslautern

Postfach 3049

KAISERSLAUTERN D-6750

GERMANY

(Tel. +49 631205 2895;

E-mail: rombach@informatik.uni-kl.)

\section{CONFERENCE ON TESTING FOR QUALITY - MTQ'96(E)}

Birmingham (UK); April 16-18, 1996. Enquiries to Fran Foster (Tel. +44 121767 2413)

\section{TWELFTH INTERNATIONAL SECURITY} CONFERENCE - IFIC SEC'96

Isle of Samos (Greece); May 21-24, 1996. Enquiries to: KYROS

77 Kountourioti St.

ATHENS 12242

GREECE

(E-mail: sec96@aegean.ariadne-t.g.)

THIRD INTERNATIONAL CONFERENCE ON SOFTWARE FOR ELECTRICAL ENGINEERING ANALYSIS AND DESIGN - ELECTROSOFT 96 San Miniato, Tuscany (Italy); May 28-30, 1996. Enquiries to:

Sue Owen

W.I.T.

Ashurst Lodge, Ashurst

SOUTHAMPTON SO40 7AA

UK

(Fax +44 (0) 1703 292853;

E-mail: CMI@ib.rl.ac.uk.) 
INTERNATIONAL CONFERENCE ON COMPUTER AIDED DESIGN IN COMPOSITE MATERIAL TECHNOLOGY - CADCOMP 96 Udine (Italy); July 1-3, 1996. Enquiries to Sue Owen, as above.

COMPUTER AIDED DESIGN, MANUFACTURE AND OPERATION IN THE RAILWAY AND OTHER ADVANCED MASS TRANSIT SYSTEMS - COMPRAIL 96
Berlin (Germany); August 21-23, 1996. Enquiries to Sue Owen, as above.

\section{TENTH INTERNATIONAL CONGRESS OF CYBERNETICS AND SYSTEMS (WOSC)}

Bucharest (Romania); August 26-31, 1996. Enquiries to: Prof. Dr. D. Drimer

Rector, Ecological University of Bucharest

4-6, Dem. I. Dobrescu Str.

70119 BUCHAREST 1

ROMANIA

(Tel. +4016137468)

\section{Special Announcement}

\section{WORLD ORGANISATION OF SYSTEMS AND CYBERNETICS - TENTH \\ INTERNATIONAL CONGRESS ON CYBERNETICS AND SYSTEMS}

\section{(August 26-31, 1996; Bucharest, Romania)}

This triennial conference is supported by many international groups concerned with management, the sciences, computers, technology systems, cybernetics and ecology. The 1996 Congress will be the tenth in the series, previous events having been held in London (1969), Oxford (1972), Bucharest (1975), Amsterdam (1978), Mexico City (1981), Paris (1984), London (1987), New York (1990) and New Delhi (1993).

The Congress will provide a forum for the presentation and discussion of current systems research in sciences, engineering and the humanities, \& theory and practice in environmental problems.

Several specialized symposia will be held during the Congress, which will focus on research and computer science, artificial intelligence, automation, robotics, cognitive science, psychocybernetics and sociocybernetics.

Suggestions for other relevant topics \& symposia are welcome. Participants which wish to present a paper are requested to submit an abridged paper (up to 1000 words, containing an abstract of 80 words) not later than 15 January 1996). Official languages: English, French \& Romanian.
Provision is also being made for poster sessions, book exhibitions, various up-to-date equipment demonstrations, a banquet and other social events.

All submissions and correspondence regarding this Congress should be addressed to: Professor eng.Dolphi Drimer, Ph.D., Rector of the Ecological University, 4-6 Dem I.Dobrescu St., 70119 Bucharest, 1, Romania; Fax: +40-1-615.03.26; Tel: +40-1-613.74.68.

\section{Deadlines:}

- 15 January 1996: 1,000-word abridged papers should be received (two copies);

- About 1 March 1996: our latest date for notifying you about acceptance of your paper;

-15 April 1996: your full paper should be received (two copies);

-1 June 1996: our date for sending you simultaneously address labels of your co-participants, with the request to send a copy of your paper to them - which will facilitate discussions during our sessions.

Please note in this respect:

1. Allow up to 14 days for air mail from outside Europe;

2. Letters to support your travel grant application will be provided upon request after tentative acceptance of your paper; therefore, if possible, send your abridged paper well before the January 15, 1996 deadline. 